p-ISSN. 2086-9029

e-ISSN. 2654-5675

Vol. 22 No. 1, Hlm. 1-158, Juni 2020

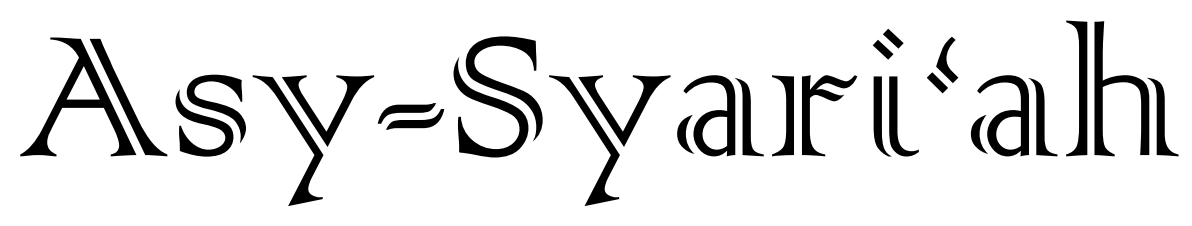

- Hukum Waris Islam Sebagai Instrumen Kepemilikan Harta

$(1-20)$ Hafidz Taqiyyudin

- Komparasi Metodologi Hukum Aliran Maqasidi dan Aliran Syakli

$(21-34)$ Hudzaifah Achmad Qotadah

- Reinterpretasi Hak Ijbar dalam Hukum Perkawinan Islam di Keluarga $(35-50)$ Pesantren

Kudrat Abdillah

- Dimensi Kondisionalitas dan Fleksibilitas Al-Quran bagi Implementasi $(51-66)$ Fatwa DSN-MUI tentang Produk Bank Syariah

Ahmad Hasan Ridwan, Asep Rahmat

- Validitas Hadis Tidak Ada Kisas bagi Orang Tua yang Membunuh Anaknya

Moh. Ahsanuddin Jauhari, Enceng Arif Faizal, Syahrul Anwar, Atep Mastur, Deden Najmudin

- Penguatan Resolusi Konflik Berbasis Tradisi Sunnah Nabi

Alamsyah

- Sistem Perencanaan, Pelaksanaan dan Pengawasan Industri Halal di Wilayah Provinsi Banten

Akhyakudin, Suja'i, Muhammad Abduh

- Reformulation of Family Legal in Indonesia for Female Maslahah

Wahidullah, Murniati, Yushinta Eka Farida, Jumaiyah

- The Concept and Aplication of Covenant in Financing Gold Pawn By Sharia Bank in West Java

Neni Nuraeni, Dewi Sulastri, Zulbaidah

- Tinjauan Sosiologi Hukum tentang Kepatuhan Masyarakat terhadap ( $147-158)$ Undang-Undang Wakaf

Deden Effendi

FACULTY OF SHARIA AND LAW

STATE ISLAMIC UNIVERSITY SUNAN GUNUNG DJATI BANDUNG-INDONESIA IN COLLABORATION WITH ASOSIASI SARJANA SYARIAH INDONESIA 


\section{Asy-Syari'ah}

Volume 22, Number 1, 2020

\section{EDITOR-IN-CHIEF}

Ine Fauzia

\section{EDITORIAL BOARD}

Sofyan al-Hakim, UIN Sunan Gunung Djati Bandung, Indonesia Deni Kamaludin Yusup, UIN Sunan Gunung Djati Bandung, Indonesia Meria Utama, Fakultas Hukum Univrsitas Sriwijaya, Indonesia Dewi Mayaningsih, UIN Sunan Gunung Djati Bandung, Indonesia Andrey Sujatmiko, Fakultas Hukum Universitas Trisakti, Jakarta, Indonesia Hetty Hassanah, Universitas Komputer Indonesia, Indonesia

\section{PEER-REVIEWERS}

Muhammad Irfan Helmy, IAIN Salatiga, Semarang, Indonesia Ahmad Ali Nurdin, UIN Sunan Gunung Djati Bandung Tajul Arifin, UIN Sunan Gunun Djati Bandung, Indonesia Mohamad Anton Athoillah, UIN Sunan Gunung Djati Bandung, Indonesia Mrs. Renny Supriyatni, Universitas Padjadjaran, Indonesia Ahmad Tholabi Karlie, UIN Syarif Hidayatullah Jakarta, Indonesia Ija Suntana, UIN Sunan Gunung Djati Bandung, Indonesia Zezen Zaenal Mutaqin, University of California, Los Angeles, United States Ahmad Fathonih, UIN Sunan Gunung Djati Bandung, Indonesia Rahman Syamsuddin, Universitas Islam Negeri Alauddin Makassar, Indonesia

\section{PROOFREADER/DESIGN COVER}

Nanang Sungkawa

\section{LAYOUT EDITOR}

Opik Rozikin

Asy-Syari' ah has been accredited based on the determination of Director General of Research and Development Strengthening, Ministry of Research, Technology and Higher Education of Republic of Indonesia, No. 14/E/KPT/2019 (valid until 2023). 


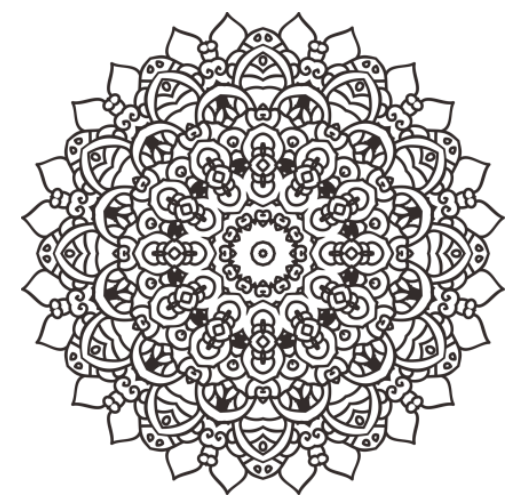

\title{
THE CONCEPT AND APPLICATION OF COVENANT IN FINANCING GOLD PAWN BY SHARIA BANKS IN WEST JAVA
}

\author{
${ }^{1}$ Neni Nuraeni, ${ }^{2}$ Dewi Sulastri, ${ }^{3}$ Zulbaidah \\ ${ }^{1}$ Syari'ah Economic Law Department of UIN Sunan Gunung Djati Bandung; \\ ${ }^{2}$ Law Department of UIN Sunan Gunung Djati Bandung; \\ ${ }^{3}$ Syari'ah Financial Management Department of UIN Sunan Gunung Djati Bandung. \\ E-mail: neninuraeni@uinsgd.ac.id, dewisulastri@uinsgd.ac.id, zulbaidah@uinsgd.ac.id
}

\begin{abstract}
One form of innovation proposed by Islamic banks to support the needs of the community is The Sharia Gold-pawning Service. However, worries arise for the Rahn service (gold pawning) since the service is not beneficial in gaining profits. By this service, Islamic banks only gain profits from the maintenance service of goods that are pledged as collateral. The problem occurs as the profit is taken from the percentage of the loan amount provided by a Sharia bank to its customer which is considered to have no cost differential as the practices undertaken in conventional banking. Therefore, this is an interesting topic to discuss among academics related to the amount and calculation of maintenance services that customers must pay to the bank. If maintenance services are determined based on the percentage of the financing or the loan amount, then there is a credit interest value on the financing that must be returned by the customer as maintenance services calculated from the loan amount. Thus, this study is intended to analyze the concept of covenant and its application in financing gold pawning in Islamic banks. The objects of this study are those concerning the Islamic Commercial Bank, including Bank Syariah Mandiri and Bank Jabar Banten Syariah.
\end{abstract}

Keywords: Bank Syariah Mandiri, Bank Jabar Banten Syariah, Gold Pawn (rahn)

DOI: 10.15575/as.V22i1.5822 
Abstrak: Salah satu bentuk inovasi yang dikeluarkan bank syariah untuk menunjang kebutuhan masyarakat adalah produk gadai emas syariah. Namun, kekhawatiran muncul terhadap produk rahn (gadai syariah) karena produk ini bukan merupakan aset produktif dalam menghasilkan keuntungan. Dengan adanya layanan ini, Bank Syariah hanya mendapatkan keuntungan dari jasa pemeliharaan barang yang dijanjikan sebagai jaminan. Permasalahan muncul ketika keuntungan diambil dari persentase besaran pinjaman yang diberikan oleh Bank Syariah kepada nasabah sebagaimana praktik di perbankan konvensional. Oleh karena itu, ini adalah topik yang menarik untuk dibahas di antara akademisi yang terkait dengan besaran dan perhitungan jasa pemeliharaan yang harus dibayar nasabah kepada Bank. Jika jasa pemeliharaan ditentukan berdasarkan persentase dari jumlah pembiayaan atau pinjaman, maka terdapat nilai bunga kredit atas pembiayaan yang harus dikembalikan oleh nasabah sebagai jasa pemeliharaan yang dihitung dari besaran pinjaman tersebut. Dengan demikian, penelitian ini dimaksudkan untuk menganalisa konsep akad dan penerapannya dalam pembiayaan gadai emas di bank syariah. Adapun obyek studi ini adalah mengenai bank komersial Islam, termasuk Bank Syariah Mandiri dan Bank Jabar Banten Syariah.

Kata-kata Kunci: Bank Syariah Mandiri, Bank Jabar Banten Syariah, Gold Pawn (rahn) 


\section{Introduction}

Islamic banking began to be widely applied in Indonesia especially after the establishment of Act No. 10 of 1998 which explains in detail of the legal foundation and types of businesses that are able to be operated and implemented by Islamic banks. The Act also directs conventional banks to adopt Sharia branches or even convert themselves totally into Islamic banks. The opportunity is appreciated enthusiastically by the banking community. A number of banks begin to provide training in the field of Islamic banking for their staff. Some of these banks want to explore establishing Islamic divisions or branches in their institutions. Moreover, other banks plan to convert themselves completely into Islamic banks. This is predicted by Bank Indonesia through holding "Sharia Banking Training" for Bank Indonesia officials from all sectors, especially those directly related to it such as DPNP (Directorate of Banking Research and Regulation), credit, supervision, accounting, research, and monetary. ${ }^{1}$

In order to encourage the development of Islamic banking; on February 10, 1999, the government through MUI (Indonesian Ulema Council) established an institution called the National Sharia Council (DSN) based on Kp-754 / MUI / II / 1999 which had the following tasks: (a) to develop Islamic values in general economic activities and finance in particular; (b) to issue a fatwa on the types of financial activities; (c) to issue a fatwa on Sharia financial services; and (d) to supervise the application of the fatwa issued.

As the increasing needs of the people, it has become one of the supporting factors for the development of Islamic banking in Indonesia. ${ }^{2}$ The presence of community needs for financing that is fast, easy, safe and certainly Sharia-triggers Islamic banking to innovate. One form of innovation issued by Islamic banks to support those needs is Sharia gold pawning services. ${ }^{3}$

On the other hand, worries constantly arise for the Rahn service (Islamic mortgage)as the Rahn service (gold pawning) is not a productive asset in generating profits. In this case, Islamic banks only take a benefit from wages for pawn maintenance which are guaranteed by customers. Problems arise when the profits are taken from the percentage of the amount of loans provided by the bank to customers as well as the practice performed in conventional banking. If such practices are performed in Islamic banks, the Syariah principle is probable to be neglected due to the calculation and determination of the amount of maintenance services for the collateral items calculated from the percentage of the amount of financing provided by the bank to the customer.

\footnotetext{
${ }^{1}$ Muhammad Syafi'i Antonio, Bank Syariah:Dari Teori ke Praktek (Jakarta: Gema Insani dan Tazkia Cendekia. 2001), p.18.

${ }^{2}$ Islamic banking is everything that concerns Sharia Banks and Sharia Business Units, including institutions, business activities, and the ways and processes in carrying out their business activities. See Article 1 paragraph (1) of Act No. 21 of 2008 concerning Sharia Banking.

${ }^{3}$ Bank Indonesia Circular Letter No.14 / 7 / DPbS dated February 29, 2012, concerning Qardh Goldbacked Services for Sharia Banks and Sharia Business Units.
} 
This is an interesting topic of discussion among academics related to the amount and calculation of maintenance services that customers must pay to the bank. Since maintenance services are determined based on the percentage of the amount of financing or loans provided by the bank to the customer, there is a credit interest value on the financing that must be returned by the customer as a collateral for maintenance services calculated from the amount of the loan. Regarding the background above, this study focuses on analyzing the concept of agreement and its application in financing gold pawning in Islamic banks.in which this study takes place in the Islamic Commercial Bank, including Bank Syariah Mandiri and Bank Jabar Banten Syariah.

\section{Methodology}

The method used in this study was the normative legal research method. Normative legal research methods or library legal research methods can be understood as methods used in legal research conducted by examining existing library materials. ${ }^{4}$ The first stage of this study concerning normative legal research was to aim at obtaining objective law (legal norms), namely by conducting research on legal issues. While for the second stage, the research was to aim at obtaining subjective law (rights and obligations).

The type of research was included in the category of case study research which meant that the law was conceptualized as a written norm in legislation or the law was conceptualized as an indicative norm. This type of case study (case approach) was a parameter that aimed to analyze the application of normative norms or regulations of law established in legal practice. Thus, this study was enabled to analyze the service of Islamic gold pawn financing performed in Islamic banks.

\section{Findings and Discussion \\ The Covenant Theory in Sharia Pawn}

Covenant has a significant meaning in social life. Through this agreement in financing needs Maliyah and Madiyah (goods and services) a person legally fulfills the 'syarak', whether the needs that are Dharuriyyah, Hajjiyah, or Tahsiniyah. A covenant is a facility for everyone in fulfilling their needs and interests that can only be done with the favor and services of others.

The word al-'aqdu (Covenant) is the Masdar form of 'aqada - ya'qidu - 'aqdan. Based on the original word, there is a development and expansion of meaning in accordance with the context of its use. For example, Aqada with the meaning of "concluding, bridging, and binding, or namely binding a promise". According to al-Jurjani, starting

\footnotetext{
${ }^{4}$ Soerjono Soekanto and Sri Mamudji, Penelitian Hukum Normatif Suatu Tinjauan Singkat (Jakarta : PT Raja Grafindo Persada. 2009), p.13-14.
} 
from the word 'aqd or ' uqdah which means "tie or knot" as found in threads or ropes, then there is an expansion of the use of the word 'aqd on any context that can be bound and the bond can be agreed. Therefore, naming the Syar'i bond between husband and wife is referred to as 'uqdatunnikah, while making ties between one another in the context of business activities such as buying and selling transactions is called 'aqdu albuyu ' by using the word 'aqad or 'uqdah. ${ }^{5}$ Whereas in a more specific term, ${ }^{6}$ that covenant is a meeting between consent and obedience as a statement of the will of two or more parties to establish a legal effect on the object.

The harmonious comparison and terms of the covenant in Islamic covenant law with the Indonesian Civil Code are used as legitimate conditions of the agreement, in terms of similar substances. In the Fiqh Muamalah, a pawn is known as a loan with a guarantee called Al-rahn, which is to store an item as a debt burden. Al-Rahn (pawn) can literally be understood as al-tsubut and al-habs namely determination and detention. In addition, some experts explain that Rahn is confined or entangled, and Rahn can also be literally interpreted as absolute, eternal, and guarantee. ${ }^{7}$ According to Zainuddin and Jamhari, to pawn is giving valuable objects from someone to other people as a guarantee or surety on accounts payable. Borg is an object that is used as collateral. An object of borg will then be taken back after the debt is paid. When the usance of payment past dues and owing, this borg is used as the substitutes by selling as the debt's payment and returning the amount of excessive value of proceeds. ${ }^{8}$

Literally, Rahn is permanent and sustainable, and also called al hasbu which means detention, as said by ni'matun rahinah which means a permanent and perpetual gift. ${ }^{9}$ While according to Syara', when a person wants to owe, the person makes his/her property in the form of immovable property or livestock under the pledger authority (obligee) until the person repays the debt. Rahn's covenant is allowed regarding the Qur'an, Al-Sunnah, and Ijma'. Allah SWT said in Surah al-Baqarah verse 283.

In relation to a review of Islamic law concerning the verse, the legal basis of a pawn is Jaiz (permitted); the scholars also agree that Rahn is permitted while not a must since pawn is only a guarantee when the two parties do not trust each other. The arguments of The Sunnah, one of the Hadith of The Messenger mentioned: ${ }^{10}$ "That The Messenger

${ }^{5}$ The word 'aqada in the Quran is found 7 times in five letters with various forms, namely 'aqadat in letter 4:33, 'uquud in letter 5: 1, 'aqadtum in letter 5:89, 'uqdatun in letter $2: 235$ and 237, 20:27; and 'uqad in letter 113:4. Regarding the 7 words, which are related to binding to the promise in Chapter $5: 1$. In this verse, Allah commands the people to keep all forms of promise, both promises with Allah and promises with fellow humans.

${ }^{6}$ Syamsul Anwar, Hukum Perjanjian Syari'ah, p.68.

${ }^{7}$ Hendi Suhendi, Fiqh Muamalah (Jakarta: PT.Raja Grafindo Persada. 2002), 1st print, p. 105.

${ }^{8}$ A. Zainuddin and Muhammad Hamhari, Al-Islam 2: Muamalah dan Ahlaq (Bandung: CV Pustaka Setia. 1999), 1st print, p.21.

${ }_{9}^{9}$ Sayyid Sabiq, Fiqh Sunnah 12 (Bandung: PT.Al-Ma'arif. 1987), 1st print, p. 150.

${ }^{10}$ Ibid., P.140. 
once bought food from a Jew in debt, he then left (mortgaged) his armor as a guarantee of his debt."

The scholars have agreed that the pawn is permissible and never contradict the agreement; likewise the legal basis. Jumhur ulama argued that the pawn was given when not traveling and when traveling. This is oriented to the actions of the Prophet Muhammad towards Jews in Medina.

It can be seen that the law lien is a highly recommended Sunnah (sunnah muakkad), since its presence affects the trust between the two sides, to prevent fraud and further losses. ${ }^{11}$ In addition to a Sharia Financial Institution in which it runs a Sharia mortgage transaction, it must comply the Sharia mortgage, including ${ }^{12}$ (a) Ar-Rahin (pledger) A person who is mature, sensible, trustful, and owns goods to pawn. (b) AlMurtahin (pledge assets) A person, bank, or institution that is trusted by rahin to obtain capital under the guarantee of goods (mortgage). (c) Al-Marhun / Rahn (pledge or pawned goods) Goods used by rahin as collateral in obtaining debt. (d) Al-Marhun bih (debt) A number of funds given by murtahin to rahin on the basis of the magnitude of the interpretation of marhun. (3) Shigat, ijab, and qabul.

The pawn covenant is basically a loan agreement with the presence of a guarantee that there is a guarantee; it is probable that the usury may occur since the agreement grants an additional value to the specified mortgage. An example of usury practice can be found is that Rahin (pledger) must provide additional compensation to the pledge asset when paying the debt, or when the mortgage agreement (that includes the compensation) is determined by the terms and it is then implemented. If the payment dues, the pledge asset has the right to sell marhun (collateral) with the actual price of the collateral. The pledge asset is only entitled to obtain is as much as the claim. If it results that the sales price of marhun is greater than the amount of debt (claim), then the rest is returned to the pledger. Conversely, the sales price of the collateral is less than the debt, the pledger still has to pay the shortfall. ${ }^{13}$ The concept of covenant used in the financing of Sharia gold pawns includes The Three Covenants (multi covenant or hybrid covenant): qardh, rahn, and ijarah.

Qardh is a financing facility provided by Islamic banks in helping small entrepreneurs. The Qardh financing is given without any compensation, The Qardh is also asset giving to other people who can be claimed or are capable of returning concerning the amount of the receivables without any additional or compensation demanded by Islamic banks. In the Oardh covenant, there are at least four elements which formulate the Qardh, namely the lender or pledger asset (muqridh), the recipient or pledger (muqta-

\footnotetext{
${ }^{11}$ Adrian Sutedi, Hukum Gadai Syariah. p.27.

${ }^{12}$ Heri Sudarsono, Bank dan Lembaga Keuangan Syariah Deskripsi dan Ilustrasi (Yogyakarta: Ekonisia. 2003), p.16o.

${ }^{13}$ Sohari Sahrani and Ru'fah Abullah, Fikih Muamalah (Bogor: Ghalia Indonesia. 2011), p.162.
} 
ridh), the object of qardh (mahall al-qardh), and the expression of consent and 'aqidain (the parties)

ljarah is the covenant of transferring the usufructuary rights of goods or services, through payment of rental cost without being followed by the transfer of ownership of the goods. In term of the practice, this activity is undertaken by leasing companies, both for operating lease and financial lease activities. ${ }^{14}$ The ljarah transaction is based on the transfer of benefits. In the ijarah covenant, there are at least four elements that form the ijarah, i.e. mu'jir and musta'jir, namely those who carry out leasing or wage covenants, ujrah (rent or wage costs known by the parties), goods leased or services provided, and expressions of consent and obedience from 'aqidain (the parties involved in the covenant).

Gold pawning services undertaken by Islamic banks are banks providing loans or financing to customers (pledgers) using qardh covenants in the context of Rahn by pawning customers' gold as collateral and the customers are required to pay maintenance or rental fee to banks regarding the ijarah principle. ${ }^{15}$ So that in gold pawning services by Islamic banks, at least three covenants are used: the qardh, Rahn, and ijarah covenants.

\section{Determining Ujrah Rates in Gold Pawn Financing Services in Islamic Banks}

The determination of maintenance fees in Islamic banks such as in Bank Syariah Mandiri implicitly use the loan amount as a reference for maintenance fees; more specifically, determining the percentage used for the appraised value, on the other hand, depends on the amount of financing. The process of appraising collateral objects is performed by pawning staff referring to the Gold Appraisal Technical Guidelines and is not permitted to use through sampling. The amount of the mortgage financing value given to the customer is calculated based on the maximum mortgage financing valuewhich is determined by the value of FTV ( Financing to Value is a comparison between the amount of the loan received by the customer and the collateral or gold object collateralized by the customer). ${ }^{16}$

Table 1. Maximum FTV

\begin{tabular}{cllc}
\hline NO. & Collateral type & $\begin{array}{c}\text { FTV Start-up } \\
\text { Financing }\end{array}$ & FTV on Extension \\
\hline 1 & Gold Jewelry & $80 \%$ of HDE & $84 \%$ of HDE \\
\hline 2 & Gold bullion (bars), coins, and dinnar & \multicolumn{2}{c}{$95 \%$ of HDE } \\
\hline
\end{tabular}

${ }^{14}$ Muhammad Asro and Muhammad Kholid, Fiqih Perbankan (Bandung: Pustaka Setia. 2011), 1st print, p.72.

${ }^{15}$ Iwan Setiawan, "Penerapan Gadai Emas pada Bank Syariah Perspektif Hukum Ekonomi Islam", AlDaulah Journal Volume 6 No. 1 April 2016, p.211.

${ }^{16}$ Manual of Bank Syariah Mandiri Gold Pawn Financing Services. 
The following is a formula for calculating the maximum mortgage liability received by the customer:

a. Value of Financing (maximum Rp. 250 million) = Appraised $x$ FTV

Appraised $=\left(\frac{\text { karat }}{24}\right.$ weight guarantee $X$ HDE $) \times$ FTV

b. The minimum tinancing value is $50 \%$ of the maximum financing limit obtained in item 1.

Example calculation:

Customer A has 6 LM Antam certified with a total weight of 600 (six hundred) grams at a rate of 24 Karat. HDE is set at Rp. 500,000, -

Value of Financing $={ }^{\frac{24}{24}} \times 600$ gram $\times$ Rp500,000, $-\times 95 \%$

$$
\begin{aligned}
& =\text { Rp. } 300,000,000 \times 95 \% \\
& =\text { Rp. } 285,000,000,
\end{aligned}
$$

Based on the calculation above, it is obtained: (a) The maximum amount of financing received by the customer is Rp.250,000,000, (b) The minimum amount of financing received by the customer is $50 \%$ of the maximum mortgage financing limit is $50 \%$ xp. 250,000,000, = Rp. 125,000,000, -

Administrative fees are costs paid by customers at the beginning of the mortgage period which include stamp costs, administrative fees, and insurance premiums. Administration fees are determined based on the amount of customer financing, with the specific amount of administrative fees explained in the table below:

\begin{tabular}{|c|c|c|c|c|c|c|c|}
\hline \multirow{2}{*}{ NO. } & \multicolumn{2}{|c|}{ Financing } & \multirow{2}{*}{$\begin{array}{c}\begin{array}{c}\text { Administrative } \\
\text { fees }\end{array} \\
\text { (Rp. 1,000) }\end{array}$} & \multirow{2}{*}{ No. } & \multicolumn{2}{|c|}{ Financing } & \multirow{2}{*}{$\begin{array}{c}\begin{array}{c}\text { Administrative } \\
\text { fees }\end{array} \\
\text { (Rp. 1,000) }\end{array}$} \\
\hline & $\begin{array}{c}\text { Min (Rp. } \\
1,000)\end{array}$ & $\begin{array}{c}\text { Max (Rp. } \\
1,000)\end{array}$ & & & $\begin{array}{l}\text { Min (Rp. } \\
1,000)\end{array}$ & $\begin{array}{c}\text { Max (Rp. } \\
1,000)\end{array}$ & \\
\hline 1 & 500 & 5,000 & 25 & 26 & 125,001 & 13,000 & 275 \\
\hline 2 & 501 & 1,000 & 35 & 27 & 130,001 & 135,000 & 285 \\
\hline 3. & 10.001 & 15,000 & 45 & 28 & 135,001 & 140,000 & 295 \\
\hline 4 & 15,001 & 20,000 & 55 & 29 & 140,001 & 145,000 & 305 \\
\hline 5 & 20,001 & 25,000 & 65 & 30 & 145,001 & 150,000 & 315 \\
\hline 6 & 25,001 & 30,000 & 75 & 31 & 150,001 & 155,000 & 325 \\
\hline 7 & 30,001 & 35,000 & 85 & 32 & 155,001 & 160,000 & 335 \\
\hline 8 & 35,001 & 40,000 & 95 & 33 & 160,001 & 165,000 & 345 \\
\hline 9 & 40,001 & 45,000 & 105 & 34 & 165001 & 170,000 & 355 \\
\hline 10 & 45,001 & 50,000 & 115 & 35 & 170,001 & 175,000 & 365 \\
\hline 11. & 50,001 & 55,000 & 125 & 36 & 175,001 & 180,000 & 375 \\
\hline
\end{tabular}

Table 2. Pawn Financing Administration Fees 
Neni Nuraeni,Dewi Sulastri, Zulbaidah, The Concept and Aplication of Covenant in Financing ... 135

\begin{tabular}{llllllll}
\hline 12 & 55,001 & 60,000 & 135 & 37 & 180,001 & 185,000 & 385 \\
\hline 13 & 60,001 & 65,000 & 145 & 38 & 185,001 & 190,000 & 395 \\
\hline 14 & 65,001 & 70,000 & 155 & 39 & 190,001 & 195,000 & 405 \\
\hline 15 & 70,001 & 75,000 & 165 & 40 & 195001 & 200,000 & 415 \\
\hline 16 & 75,001 & 80,000 & 175 & 41 & 200,001 & 205,000 & 425 \\
\hline 17 & 80,001 & 85,000 & 185 & 42 & 205,001 & 210,000 & 435 \\
\hline 18 & 85,001 & 90,000 & 195 & 43 & 210,001 & 215,000 & 445 \\
\hline 19 & 90,001 & 95,000 & 205 & 44 & 215,001 & 220,000 & 455 \\
\hline 20 & 95,001 & 100,000 & 215 & 45 & 220,001 & 225,000 & 465 \\
\hline 21 & 100,001 & 105,000 & 225 & 46 & 225,001 & 230,000 & 475 \\
\hline 22 & 105,001 & 110,000 & 235 & 47 & 230,001 & 235,000 & 485 \\
\hline 23 & 110,001 & 115,000 & 245 & 48 & 235,001 & 240,000 & 495 \\
\hline 24 & 115,001 & 120,000 & 255 & 49 & 240,001 & 245,000 & 505 \\
\hline 25 & 120,001 & 125,000 & 265 & 50 & 245,001 & 250,000 & 515 \\
\hline
\end{tabular}

Maintenance fees are paid by the customer to the Bank at the end of the period or when the customer completes the financing for maintenance services of collateral goods during the period of mortgage financing. The amount of maintenance fees is determined as follows: (a) The amount of maintenance fees is based on a certain percentage of the appraised value; (b) Maintenance fees are determined as in the following table:

Table 3. Price of Maintenance Based on Type of Guarantee and Amount of Financing

\begin{tabular}{cccc}
\hline $\begin{array}{c}\text { Guarantee } \\
\text { type }\end{array}$ & Grade & Range of Financing & $\begin{array}{c}\text { (e.q. rate / month) } \\
\text { Towards Appraised } \\
\text { Value }\end{array}$ \\
\hline & 1 & 500 thousand $\leq X \leq 20$ million & $1.70 \%$ \\
\hline A & 2 & 20 million $<X \leq 50$ million & $1.53 \%$ \\
\cline { 2 - 4 } & 3 & 100 million $<X \leq 250$ million & $1.49 \%$ \\
\hline B & 4 & 100 million $<X \leq 250$ million & $1.45 \%$ \\
\hline
\end{tabular}

Description: (a) Type of guarantee A: in the form of gold bullion, Precious Metals (LM) / Antam Dinars without certificates, LM, and gold jewelry. (b) Type of guarantee B: in the form of LM or Antam Dinar and PT Peruri's joint Dinar.

Other fees are costs incurred by customers other than administrative fees and maintenance fees, including the following: 1) Fees incurred at the time of sale of collateral (if the Customer cannot pay off the financing at maturity). This fee takes into 
account the fees incurred during the process of selling the collateral.2) The fee is charged if the Customer has not taken the collateral, while the facility has been repaid. The amount of the amount of custody refers to the smallest save deposit box size and plus an insurance fee of $0.133 \%$ of the appraised value calculated in daily proportions.

For example, if a customer has gold bullion with an appraised value of Rp. $30,000,000$, and the disbursement date January 1, 2017, the calculation is as follows:

a. The maximum funding is the Appraised $x$ FTV Value (95/80\%). ${ }^{17}$

Rp. 30,000,000 × 95\% (gold bullion) $=$ Rp. 28,500,000,

b. Minimum loan financing $50 \%$ of appraised value. ${ }^{18}$

IDR 30,000,000 × 50\% = IDR 15,000,000

Based on the above calculations, customers can borrow between Rp. 15,0000,000 Rp. 28,500,000. To determine maintenance fees, use certain percentages ${ }^{19}$ of appraised value. The text will be obtained as follows: (a) If the customer submits financing under Rp. $20,000,000$, - then the calculation is, $1.70 \%$ of the RP. $28,500,000=$ Rp. $484,000 /$ two periods (months) . (b) If the customer submits financing above Rp.20,000,000, - then the calculation is, $1.53 \%$ of Rp. $28,500,000=$ Rp. 435,050 if applying for financing above Rp. $20,000,000 /$ two periods (months) .

Based on the two calculations above, the determination of the amount of maintenance fees charged to the customer if the loan amount is above Rp. 20,000,000 is Rp. 484,000 / two periods (months) with due dates May 1, 2017. If the loan amount is under Rp. 20,000,000 is Rp. 435,050 / two periods (months) with due dates May 1, 2017. As for the administrative fees charged are:

a. If the loan is between Rp. 15,001,000 - Rp. 20,000,000, the administrative fee is Rp. 55,000 .

b. If the total loan is Rp. $20,001,000-$ Rp. $25,000,000$, the administrative fee is Rp. 65,000 .

c. If the loan is Rp. $25,001,000$ - Rp. $30,000,000$, the administrative fee is Rp. $75,000,000$.

Determination or calculation of guarantee object maintenance fees on the gold pawning financing services at Bank Syariah Mandiri above is different from the ujrah financing applied by Bank Jabar Banten Syariah. Maintenance fees or ujrah rates are the cost of storing goods that are used as collateral for pawns at the BJB Syariah Bank. The imposition of Ujrah rates at the BJB Syariah Bank and followed by the BPD-BPD which has a pawn service is different from the ujrah rates applied in a private bank. This

\footnotetext{
${ }^{17}$ See Table 1. Maximum FTV

${ }^{18} \mathrm{BSM}$ gold pawn financing service manual.

${ }^{19}$ See Table 3.Maintenance Fee (Price) based on the type of guarantee and amount of financing.
} 
difference is due to the fact that the DSN fatwa and the existing regulations do not regulate technically the ujrah rates calculation. The determination of ujrah rates at the BJB Syariah Bank starting April 5, 2015, is as follows:

Table 4. Terms of Ujrah Rate in BJB Syariah Bank

\begin{tabular}{|c|c|c|c|}
\hline \multirow{2}{*}{ NO. } & \multirow{2}{*}{ Karatase (purity) } & Maintenance Fees ( ujrah) & \multirow{2}{*}{ FTV } \\
\hline & & per gram per month & \\
\hline 1 & 16 & Rp. 4,450 & $85 \%$ of HSE \\
\hline 2 & 17 & Rp. 4,450 & \\
\hline 3. & 18 & Rp. 4,500 & \\
\hline 4 & 19 & Rp. 4,500 & \\
\hline 5 & 20 & Rp. 4,600 & \\
\hline 6 & 21 & Rp. 4,600 & \\
\hline 7 & 22 & Rp. 4,650 & \\
\hline 8 & 23 & Rp. 4,650 & \\
\hline 9 & 24 & Rp. 4,750 & $90 \%$ of HSE \\
\hline
\end{tabular}

Gold pawning at the Syariah BJB Bank, at first, was not intended to get a fee base but rather aimed to enliven the bank and introduce Islamic banks to the public. The fee base from the mortgage is intended to cover operational fees not to earn profits. However, it was in line with business development, especially when 'spin-off' of gold pawning at Syariah BJB Bank was improved to become a profit center as well as an icon of BJB Syariah Bank itself. Therefore, the vision and mission of gold pawning at BJB Syariah Bank have changed, no longer aiming to enliven a newly established bank, but to become a profit center that is passed on to the platform to become a profit source or fee base. As time passed, the cost of a mortgage becomes more expensive since the mission and vision of this mortgage service have changed.

Ujrah rates at BJB Syariah Bank are charged upfront and are calculated from the weight of the item regardless of the amount or size of the loan. This has consequences for the selling price of the product itself, will be more expensive or can be cheaper since the costs are not associated with loans. This is different from ujrah rates which are associated with loans both directly and indirectly. In the case of Sharia gold mortgage fees, ujrah at BJB Syariah Bank is known to be cheaper than other banks other than ujrah there is no other fee in the mortgage at BJB Syariah Bank because the ujrah or savings fee includes insurance fees and administrative fees

In determining the ujrah rate or the rental fee determination, it must be based on the Asset Liabilities Management (ALMA) Meeting which is attended by members of Asset Liabilities Committee (ALCO) held at the early month. The results of the meeting then announce Gold Appraised Values (HSE), Ujrah rates (land rental fees), and Financing 
to Value (FTV) for financing gold pawns. The announcement is issued in the form of a Circular signed by the Treasury Division Leader.

The maintenance fee and grace period are determined regarding the net gold weight rounded up multiplied by the rate based on The Decision Letter itself. The following is how the calculation of ujrah rates and the amount of loans provided by banks: For example, a customer wants to apply for a gold pawn with a type of precious metal gold which has a weight of 1ogram gold with HSE at that time is Rp.465,000, the calculation of the amount of financing and ujrah rates are as follows:

Appraised $=10$ gram $\times$ Rp. 465,000

$$
=\text { Rp.4,650,000; }
$$

Financing $=90 \% \times$ Appraises

$$
\begin{aligned}
& =90 \% \times \text { Rp. } 4,650,000 \\
& =\text { Rp. } 4,185,000 ;
\end{aligned}
$$

For precious metals weighing 10 grams, the bank can provide financing of $90 \%$ or equivalent to Rp. $4,185,000$, - while the amount of the ujrah rate that must be paid by the customer for the financing is:

Ujrah

$$
\begin{aligned}
& =\text { Rp.4,750 per gram } / \text { month } \\
& =1 \text { month } \times \text { Rp.4,750 } \times 1 \text { gram } \\
& =\text { Rp.47,500 } / \text { month }
\end{aligned}
$$

So, the amount of ujrah that must be paid by customers for precious metals weighing 10 grams is Rp.47,500 / month. As for the type of jewelry calculation is as follows: For example, another customer wants to submit a gold pawn with the type of jewelry weighing 1ograms and karatase (purity) 22k with HSE Rp. 465,000, then the calculation is as follows:

$$
\begin{aligned}
& \text { Appraised }=10 \text { gram } \times \text { Rp. } 465,000 \times 22 / 24 \mathrm{k} \\
& =\mathrm{Rp} .4,262,500 ; \\
& \text { Financing }=85 \% \times \text { Appraises } \\
& =85 \% \times \text { Rp. } 4,262,500 \text {; } \\
& =\mathrm{Rp} \cdot 3 \text {. } \\
& \text { Ujrah } \quad=\text { Rp. } 4,650 \times 10 \text { gram } \\
& =\text { Rp. 46,500/month }
\end{aligned}
$$

\section{Compliance of Sharia Banks in Determining Ujrah Rate in Gold Pawn Financing Services}

The Gold Pawn Service in BJB Syariah Bank in the branch organizational structure is under the operational part and is responsible for the operational manager and is in the Front Liner section. While on the business side is responsible to the business manager for the Main Branch Office or to the Branch Office Assistant at the KCP. Organizationally, at the pawn service center office is within the Financing Division; therefore, everything 
related to the development of the pawn business becomes the responsibility of the finance division.

The issuance of DSN Fatwa No. 25 / DSN-MUI / III / 2002 concerning Rahn and No. 26 / DSN-MUI / III / 2002 on Gold Rahn is the starting point of the establishment of the pawn system in Islamic banking. This has become a new history in the financial sector in Indonesia where previously the Pegadaian Public Company was the only business entity that officially had permission to carry out the activities of financial institutions-in which it is in the form of funding to the public on the basis of mortgage law as referred to in the Indonesia Civil Code Article 1150.

In general, the main purpose of establishing a pawn unit in Islamic banking is to serve the needs of the community for fast, easy, and cheap funding regarding the Sharia provisions. This is in line with the government's mission through $\mathrm{PP}_{103}$ of 2000 concerning Pawnshop Corporation, namely: (a) Also improving the welfare of the community, especially the middle and lower classes; and (b) Avoiding people from illegal pawn, usury practices, and other unnatural loans.

The National Sharia Council basically stipulates that the law of the Rahn covenant as a legal contract and in-line with Sharia; therefore, the Rahn covenant can be used as a contract in a Sharia service. The ability to use services using the Rahn covenant is regulated in DSN fatwa No. 25/DSN-MUI/IV/2002 concerning Rahn. The consideration of this fatwa's significance is due to the field that one form of financial services for the public is a loan pawning-goods activity. Additionally, it needs to be responded in various LKS programs. In order for the Rahn activity to be carried out in accordance with Sharia principles, the DSN considers it as necessary to establish a fatwa on Rahn to be used as a guideline for LKS in providing a scheme by pawning goods regarding Sharia principles.

IB Maslahah Gold Partners that is offered by BJB Syariah banks must also be guided by the DSN fatwa provisions. Then to find out the suitability, an analysis is needed. The analysis of this study focuses on the aspects of mechanisms and procedures, collateral (marhun), utilization of marhun, and the provisions of BJB Syariah banks related to maintenance and storage fees or often referred to as ujrah, as follows: (a) the mechanism of BJB Syariah Bank refers to the provisions of the DSN Fatwa No. 25/DSNMUI/III/2002. (b) Guaranteed Goods ( marhun ), in the application of the iB Maslahah Gold Partner, collateral goods are in the form of gold jewelry, gold bullion (precious metals), and gold coins. The collateral is held and is under the control of the bank acting as murtahin.This follows the provisions contained in the fatwa made by the National Sharia Board No. 25 / DSN-MUI / III / 2002 above. (c) Utilization of the Law, the ownership of collateral remains in the hands of the customer and the bank is not entitled to use the goods except with the permission of the customer. Provisions related to the utilization of marhun at BJB Syariah bank are also in accordance with the provisions of DSN fatwa No. 25 / DSN-MUI / III / 2002. (d) Terms and Policies of BJB Syariah Bank 
Regarding Maintenance and Storage Fees (ujrah). Shariah gold pawn is one of the transactions that are currently very popular with the public since the process is easy and does not require a long time.

Basically, pawning uses the qardh covenant included in the tabarru covenant is a covenant to help without any additions. However, in the context the increasing public interest in Sharia gold pawning, Islamic financial institutions make this gold pawn service a social-commercial service. Gold pawning can be a commercial service by using the ijarah covenant which through the ijarah agreement, the bank can take advantage of the cost of renting (ujrah) where the pledged goods are stored.

However, the current issue that the bankers are worried about is that because of the growing interest of the community, it is feared that Sharia financial institutions will be lulled by the profits that the bank gets, so that it can eventually lead to usury. In a gold pawn transaction, the practice of usury can arise when a bank calculates ujrah rate based on the size of the loan not based on the weight of the gold pawned. The terms of the ujrah rates are regulated in the DSN fatwa even though it is not explained in detail regarding the technical calculations, the cost of the ujrah is regulated in DSN fatwa No. 25 / DSN-MUI / III / 2002 in point four which states that the maintenance and storage fees of Marhun must not be determined based on the amount of the loan, then in the DSN fatwa No. 26 / DSN-MUI / III / 2002 it was also explained that the costs and storage costs of large goods must be based on actual expenditure needed, and the cost of storing goods ( marhun ) is concerning ijarah covenant. Since the rental cost is based on the ijarah covenant, the provisions must also be regarding DSN fatwa No. og/DSN-MUI/IV/ 2000 stating that:

First, Rent or wages must be agreed upon in the covenant and must be paid by the lessee/service user to the lever/service provider (LKS) as a payment of benefits or services. Something that can be used as a price ( tsaman ) in buying and selling is also used as rent or wages in ijarah, Second, Payment of rent or wages may take the form of services (other benefits) of the same type as an object of the covenant; and, Third, Suppleness (flexibility) in determining rent or wages can be included in the measurement of time, space and distance.

In addition to being explained in the fatwa of the National Sharia Council, SEBI also describes in related to ujrah rate provisions, which are listed on SEBI No. 14/7 / Dpbs regarding Qardh Gold-backed Services for Sharia Banks and Sharia Business Units, stating that: Sharia or UUS to customers include administration fees, insurance fees, storage fees, and maintenance fees; and b) Determination of the amount of the cost of storing and maintaining gold collateral is based on the weight of the gold collateral and is not related to the number of loans received. 
Based on SEBI No. 14/7/Dpbs above, it can be concluded that the Sharia gold pawn financing is a transaction that is permissible and legal; but when the bank calculates ujrah rates based on the amount of the loan, this transaction becomes illegitimate since it is categorized as the practice of usury.

BJB Syariah Bank sets the Gold Standard Price of iB Maslahah Gold Partner Financing (HSE), which is Rp. 459,000- / gram. The Gold Standard Price (HSE) and the ujrah rate are determined based on the Asset Liabilities Management (ALMA) Meeting attended by members of the Asset Liabilities Committee (ALCO) held at the early month. The meeting the results that the Gold Appraised Values (HSE), Ujrah rates (place rental fees), and Financing to Value (FTV) will be announced for gold pawn financing. The announcement is issued in the form of a Circular signed by the Treasury Division Leader.

Concerning the execution of the gold pawning transaction at the BJB Syariah bank: the customer, firstly, comes to the BJB Syariah bank by bringing the goods to be pawned (gold jewelry, precious metals, or gold bars); the goods are then appraised based on the type. In relating to the appraisal process, the type of jewelry is checked towards the authenticity and the karatase (purity) by using two types of liquids: test liquid 1 and test liquid 2, in order to find out whether the metal is genuine or not. The process is performed twice in which the goods are appraised by using one test liquid in rubbing due to reveal the gold contained. During the test, the metal can be identified as not gold when the color contained in the metal disappears immediately, otherwise, the metal is gold, the color of the metal materializes when rubbed using test liquid 1 . Whereas to find out the type of karatase (purity), it is performed by using liquid test 2, if the color of the metal is quickly lost then the karatase (purity) are low, but if it is not easily lost then the karat is high.

After assessing the mortgage, the next process is calculating the amount of loans that the bank can give to the customer, the amount of the loan can be seen from the table above, namely for gold jewelry loans of $85 \%$ of the gold standard price while for precious metals, the customer will be given a loan amounting to $90 \%$ of the price of the gold standard. Then, to determine the ujrah rates to be paid by customers, banks calculate it based on the weight of gold pledged instead of the number of loans. The table above also indicates the nominal amount listed for the ujrah rate that contains different karatase (purity). Thus, the more specified Ujrah calculation pattern is as follows:

Firs, Precious metal

For this type of precious metal the bank calculates the amount of loans that can be given to customers using the formula:

Appraised $=$ Gold Weight $\times$ Gold Standard Price (HSE)

Financing $=90 \%$ (for precious metals) $\times$ Appraises

Ujrah $=$ Pawn Period $\times$ Rate of Ujrah $\times$ Weight of Gold 
Second, Gold Jewelry

For the type of gold jewelry, the calculation procedure is the same as the calculation on precious metals but is only different in the amount of financing, such as:

Appraised $=$ gold weight $\times$ Gold Standard Price (HSE) $\times$ karatase (purity) / 24

Funding $=85 \%$ (for gold jewelry) $x$ appraises

Ujrah = Rate of ujrah $\times$ Weight of gold

Based on the information above, BJB Syariah Bank stipulates the ujrah rate based on the weight of gold besides the number of loans. The implementation of the gold pawning transaction at BJB Syariah bank is in line with Sharia rules regarding DSN Fatwa No. 26/DSN-MUI/III/2002 concerning Gold Rahn and other related laws.

This is different from the case for establishing maintenance fees on gold pawn financing services at Bank Syariah Mandiri. Determination of maintenance fees in Bank Syariah Mandiri does not explicitly use the loan amount as a reference for maintenance fees. However, as more specifically analyzed, determining the percentage used for the appraised value is seen to depend on the amount of financing. Referring to the provisions of the DSN-MUI Fatwa No. 25, in general provisions point 4, namely: "The fee of maintenance and storage of Marhun may not be determined based on the loan". The calculation of maintenance fees is calculated in multiples of fifteen days. If the customer makes an early repayment, the customer will still be charged a maintenance fee that is calculated per 15 days or if the customer accelerates repayment on the 17th day, the customer will be counted in two periods and must pay according to the two periods. In this case, the customers pay maintenance fees that do not exist. So this maintenance fee is meant by usury since it requires an addition without the equivalent. Require additional fees imposed on gold pawn financing transactions that are calculated from the principal of the loan without considering the utilization/yield of the principal, based on the time period, calculated accurately in advance and generally based on percentage. Thus, additional calculations by means of calculations like this have already been felt to be contrary to the implementation of Sharia principles because they contain elements of usury and dzalim (oppressive).

Gold pawn financing in Sharia financial institutions (Islamic banking) uses a multicovenant concept, meaning that the covenant used in this type of gold pawn financing service uses three covenants, namely the qardh, rahn, and ijarah covenants. These three covenants have different characteristics so that they will have implications for their application when used in gold pawn financing in Islamic banks.

The imposition of this maintenance fee is basically not in the Rahn covenant as Rahn is a contract for guaranteeing goods for debt. However, the imposition of maintenance fees is a consequence of the fee towards maintaining or renting space for objects or goods (marhun) guaranteed by pledge asset to pledger. Therefore, it is more appropriate to be included as an ijarah covenant. In the MUI DSN Fatwa No. 25/DSN- 
MUI/III/ 2002 concerning Rahn, no explicit mention is made of the ijarah covenant in the Rahn covenant. However, in the MUI DSN Fatwa No. 26/DSN-MUI/III/ 2002 concerning Gold Rahn, it is proven that the existence of the ijarah covenant in the fatwa is expressly stated in point 4 (four). Therefore, when carrying out the Rahn gold-pawning covenant, the maintenance fee clause is included in the covenant. The amalgamation of these two covenants in one covenant makes it a murakkab covenant (multi covenant). Murakkab here belongs to the group al-'uqud al-mujtami'ah. ${ }^{20}$

Based on the explanation above, this study finally formulates that gold pawn financing in Islamic banks uses three covenants: the qardh covenant as a loan-borrowing or debt-credit covenant, Rahn covenant as a guarantee covenant in the form of goods, and ljarah covenant as the consequences of gold Rahn. While the cost of rental fees for marhun guaranteed by rahin (customers) to murtahin (Islamic banks) is covered by rahin (customers). The amount of the cost for the rental place must not be calculated from the percentage of financing or loans provided, but the amount of the cost is taken from the factual needs. Provisions regarding fees or rental fees are determined by each bank by looking at the weight of gold used as collateral and the length of the lease until rahin (the customer) can repay the loan provided by murtahin (Islamic bank). If the determination of rental fees ( ujrah) is calculated from the percentage of financing or loans ( qardh ), then it will fall into the practice of usury, and the possibility of falling into usury fadhl.

\section{Conclusion}

Based on the results of the analysis on the Sharia banks, it can be concluded that (a) The mechanism for the implementation of the gold pawning transaction at the Syariah Bank uses three covenants: qardh covenant as a loan agreement, rahn as a guarantee covenant, and ijarah as a leasing covenant. To get financing through this gold pawning service, the customer initially comes to the bank while carrying gold as pledged goods, then the gold will be appraised to check the appropriateness. As the gold is shown as appropriate, the customer is agreed to proceed to the next process which is the process of calculating the amount of financing to be provided and determining ujrah rates that must be paid by the customer. The customer will be given financing of $85 \%$ $90 \%$ of the appraises for the type of gold jewelry or precious metal (depending on each bank policy); (b) Determination of ujrah rate in the service of gold pawn financing at

${ }^{20} \mathrm{Al-}$ 'Uqud al-Mujtami'ah is a multi-covenant that is gathered in one contract. This mujtami'ah multi covenant can occur with the accumulation of two contracts that have different legal consequences in one contract for two objects with one price, two different contracts of legal consequences in one contract for two objects with two prices, or two contracts in one contract different laws for one object with one reward, either at the same time or at a different time. For example: "I sell this house to you and I rent another house to you for one month at a price of five hundred thousand".See Hasanudin, (2008"Konsep dan Standar Multi Akad dalam Fatwa Dewan Syari'ah Nasional Majelis Ulama Indonesia (DSN-MUI)", Post-graduate Dissertation of UIN Syarif Hidayatullah in Jakarta, p .61. 
Syariah Bank is different. For example, in Bank Syariah Mandiri performs the determination of ujrah rate concerning the size of the loan, while the determination of ujrah rate at the BJB Syariah Bank is concerned about the weight of gold and the amount of karatase (purity) that is collateralized by the customer; (c) The financing of gold pawning in Islamic banks uses three covenants: qardh covenant as a loan-borrowing or debt-credit contract, rahn covenant as a trust guarantee contract in the form of goods, and ijarah covenant is a consequence of the rahn gold covenant. In addition, the cost of rental fees for marhun guaranteed by rahin (customers) to murtahin (Islamic banks) is covered by rahin (customers). The amount of the land (place) rental cost must not be calculated from the percentage of financing or loans provided, but the amount of the cost is taken from the actual need's expenditure. Provisions regarding wages or rental fees are determined by each bank by concerning the weight of gold used as collateral and the length of the lease until rahin (the customer) can repay the loan provided by murtahin (Islamic bank). If the determination of wages or rental fees (ujrah) is calculated from the percentage of financing or loans (qardh), then it will fall into the practice of usury, and the possibility of falling into usury fadhl.

\section{BIBLIOGRAPHY}

Amin, Ma'ruf. Fatwa dalam Sistem Hukum Islam, Jakarta: elSas, 2011.

Antonio, Muhammad Syafi'ı. Bank Syariah:Dari Teori ke Praktek. Jakarta: Gema Insani dan Tazkia Cendekia, 2001.

Antonio, Muhammad Syafi'i. Bank Syari'ah bagi Bankir dan Praktisi Keuangan (Jakarta: Tazkia Institute, 1999.

Anwar, Syamsul. Hukum Perjanjian Syari'ah. Jakarta: PT RajaGrafindo Persada, 2010.

Asro, Muhammad dan Kholid, Muhammad. Fiqih Perbankan, Bandung: Pustaka Setia. 2011.

Hakim, Atang Abd. Fiqih Perbankan Syariah, Bandung: Refika Aditama, 2011.

Hasanudin "Konsep dan Standar Multi Akad dalam Fatwa Dewan Syari'ah Nasional Majelis Ulama Indonesia (DSN-MUI)", Disertasi Sekolah Pascasarjana UIN Syarif Hidayatullah Jakarta Tahun 2008.

Hernoko, Agus Yudha. "Lembaga JaminanHak Tanggungan Sebagai Penunjang Kegiatan Perkreditan Perbankan Nasional", Tesis di Universitas Airlangga Surabaya Tahun 1998.

Ismail. Perbankan Syariah, Jakarta: Kencana Prenada Media Group. 2011.

Karim, Adiwarman. Bank Islam Analisa Fiqih dan Keuangan, Jakarta: PT. RajaGrafindo Persada, 2011. 
Neni Nuraeni,Dewi Sulastri, Zulbaidah, The Concept and Aplication of Covenant in Financing $\ldots \mid 145$

Manual Produk Pembiayaan gadai emas Bank Syariah Mandiri.

Al Arif, Nur Rianto. Lembaga Keungan Syariah Suatu Kajian Teoritis Praktis. Bandung: CV Pustaka Setia, 2012.

Sabiq, Sayyid. Fiqh Sunnah, Bandung: PT. Al-Ma'arif, 1987.

Sahrani, Sohari dan Abullah, Ru'fah. Fikih Muamalah, Bogor: Ghalia Indonesia. 2011.

Setiawan, Iwan. "Penerapan Gadai Emas pada Bank Syariah Perspektif Hukum Ekonomi Islam", Jurnal al-Daulah Volume 6 Nomor 1 April 2016.

Sudarsono, Heri. Bank dan Lembaga Keuangan Syariah Deskripsi dan Ilustrasi, Yogyakarta: Ekonisia, 2003.

Suhendi, Hendi. Fiqh Muamalah, Jakarta: PT. Raja Grafindo Persada, 2002.

Surat Edaran Bank Indonesia No.14/7/DPbS Tanggal 29 Februari 2012 perihal Produk Qardh Beragun Emas bagi Bank Syariah dan Unit Usaha Syariah.

Undang-Undang Republik Indonesia Nomor 21 Tahun 2008 tentang Perbankan Syariah.

Zainuddin, A. dan Hamhari, Muhammad. Al-Islam 2: Muamalah dan Ahlaq, Bandung: CV Pustaka Setia, 1999. 
146 | Asy-Syari'ah Vol. 22 No.1, Juni 2020 
Asy-Syari'ah (P-ISSN: 2086-9029 E-ISSN: 2654-5675) is a periodical scientific journal that publishes various results of studies and research, literature review, and other scientific works whose scope covers the field of Islamic law/sharia, law and society in monodisciplinary, interdisciplinary, and multidisciplinary manners. The journal aims to expand and create innovative concepts, theories, paradigms, perspectives and methodologies in the above said scope. The Journal is published twice a year (june and december) by Faculty of Shariah and Law, Sunan Gunung Djati State Islamic University Bandung in collaboration with Asosiasi Sarjana Syariah Indonesia (ASSYI).

\section{EDITORIAL OFFICE:}

Fakultas Syariah dan Hukum UIN Sunan Gunung Djati Bandung J1. Raya A.H. Nasution No. 105 Cibiru Kota Bandung, 40614

Tlp/Fax: +022-7802278 Faks. 022-7802278

Website http://journal.uinsgd.ac.id/index.php/asy-syariah/index

E-mail: Jurnalasy-syariah@uinsgd.ac.id 